\title{
Stem Cells Bioprocessing: An Important Milestone to Move Regenerative Medicine Research Into the Clinical Arena
}

\author{
JULIA M. POLAK AND SAKIS MANTALARIS \\ Department of Chemical Engineering, Faculty of Medicine and Faculty of Engineering, Imperial College London, \\ London SW7 2AZ, United Kingdom
}

\begin{abstract}
Regenerative Medicine is a new, multidisciplinary field that combines expertise in biology, chemistry, engineering, materials, and medicine, to find solutions to some of the most challenging medical problems faced by humankind. Regenerative Medicine has the potential to impact the whole spectrum of health care, such as heart disease, emphysema, and diabetes. Regenerative Medicine employs various combinations of specially grown cells, tissues, and laboratory-made compounds to replace or amplify the body's natural healing process. The impact of Regenerative Medicine to the health care industry is likely to be comparable with that of antibiotics, vaccines and lately, monoclonal antibodies have had in clinical care. Regenerative Medicine is growing and maturing steadily; however, many challenges lie ahead. These include best cell source, most appropriate biomaterials, and reliable ways of expanding the cells and growing them in a three-dimensional environment (stem cell bioprocessing). This concise review deals with current achievements in the field, challenges that lie ahead and potential ways of having robust and reliable "off the shelf" cellular products. (Pediatr Res 63: 461-466, 2008)
\end{abstract}

$\mathrm{R}$ egenerative medicine is a new interdisciplinary field aiming to provide safe and reliable ways to repair, restore, or replace damaged tissues or organs. The two main components of Regenerative Medicine are stem cell therapy and Tissue Engineering. Regenerative Medicine focuses on the mobilization of endogenous sources of "reparative" cells, most commonly stem cells, or by exogenous administration of cells. In contrast, Tissue Engineering combines specially designed materials with cells, in a three-dimensional (3D) configuration, cultured in a bioreactor, for subsequent implantation (1).

Before Regenerative Medicine and Tissue Engineering can be made widely available as a clinical product, a number of major (Fig. 1) and specific challenges (Table 1) need to be overcome. A combination of generic, off-the-shelf, and personalized manufacturing paradigms must be considered as no single technology satisfies all requirements.

Received December 11, 2007; accepted January 22, 2008.

Correspondence: Julia M. Polak, M.D., DSc, Imperial College London, South Kensington Campus, Faculty of Medicine and Faculty of Engineering, Department of Chemical Engineering, Exhibition Road, London SW7 2AZ, United Kingdom; email: julia.polak@imperial.ac.uk

\section{CELLS}

A variety of cells have been used for cell therapy or Tissue Engineering. In the early days, adult stem cells were frequently used. These were obtained from experimental animals or human tissues and were used primarily to understand the mechanisms by which natural or man-made biomaterials were able to elicit a cellular response when implanted in vivo (see later). It was later realized that adult cells, by the nature of being fully developed, were harder to grow in culture and if the cells come, as they usually do, from an elderly patient, growth of cells in culture is even harder. Hence, attention was focused onto the use of fetal cells. Fetal cells are not stem cells; they are fully developed cells that are present in young tissue (e.g., the fetus). It was found that these cells behaved similarly but better than adult, when tested in conjunction with biomaterials (2-4).

In view ${ }^{1}$ of this, further attention was focused on the potential use of stem cells for Regenerative Medicine. Stem cells are cells that have the following capabilities: first, they are able to continuously produce daughter cells having the same characteristics as themselves; second, they can generate daughter cells that have different, more restricted properties (5). The first ability is called self-renewal and the second, differentiation.

Embryonic stem cells. Until now, current thoughts were that there were two kinds of stem cells: embryonic stem (ES) cells derived from the inner cell mass of preplantation embryos and "adult" stem cells found in tissues or organs. However, recent research indicates that ES cells can be found at all stages during development (Fig. 2) (6). ES cells differentiate in vitro and in vivo and contribute to chimaeras after injection into a blastocyst (Fig. 3). Because of their limitless therapeutic potential, stem cells continue to be of enormous public, scientific, and clinical interest. If it were possible to determine which factors are involved in each and all stages during differentiation from pluripotency to terminally differ-

Abbreviations: 2 (3) D, 2 (3) dimensional; EC, embryonal carcinoma; ES, embryonic stem; EpiSC, epiblast stem cells; FITR, Fourier iterative transform X-ray; GMP, good manufacture practice; HARV, high aspect ratio vessels; HSCs, hemopoietic stem cells; ICM, inner cell mass; mESCs, mouse embryonic stem cells; MSCs, mesenchymal stem cells 
MAJOR GENERAL CHALLENGES IN REGENERATIVE MEDICINE

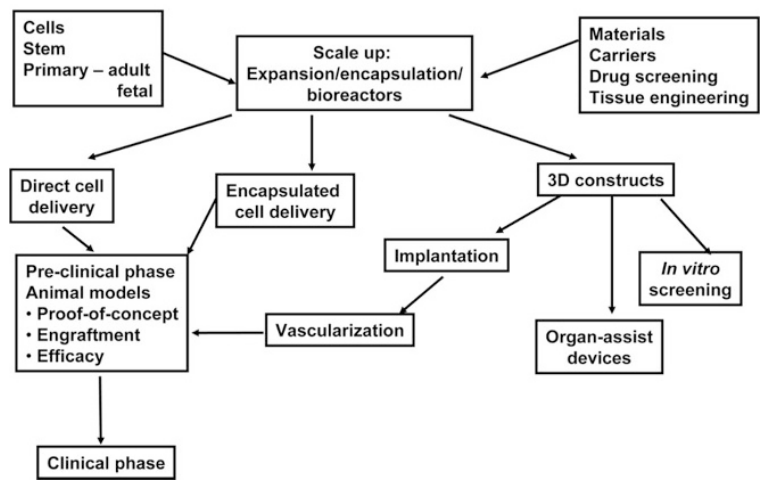

Figure 1. Depicts the major challenges faced by the field of Regenerative Medicine.

Table 1. Specific challenges*_-design consideration

Process components (cell source, cell signals, scaffolds,

bioreactors)

Process requirements (GMP, bioprocessing, preservation, transport, storage, regulators)

Process function (organogenesis, functionality, host tissue integration, immunoacceptance, longevity)

* The specific challenges that are faced to translate research in Regenerative Medicine into products for the health care industry.

entiated cells, it may be feasible, ultimately, to use these chemical signals to induce growth and regeneration of specific tissues ("regenerative pill") without the need of administering the cells themselves.

ES cells were first isolated from the mouse by Martin Evans and coworkers, back in 1981 who this year received the Novel Prize (7) and later in 1998 (8) from the human preimplantation embryo (blastocysts). This led to an unprecedented interest in the potential of ES cells for Regenerative Medicine (8). Recently, two different groups have reported the isolation of pluripotent stem cells from the epiblast dissected from early postimplantation mouse embryos using culture conditions identical to those favored by human embryonic stem cells (hESCs) $(9,10)$. In all respects tested so far, they seem to correspond closely to human rather than mouse embryonic stem cells (mESCs) (they are leukemia inhibitory factor and bone morphogenic protein independent whereas mESCs require these factors and require instead activin and fibroblast growth factor for efficient self-renewal). They have the same physical appearance, growth properties and epigenetic state as hESCs. These cells are called epiblast stem cells (EpiSCs). To add more excitement to the field, recently, four separate groups of investigators have been able to generate pluripotent stem cells by transfecting mouse $(11,12)$ and human fibroblasts $(13,14)$ with retroviruses expressing four transcription factors involved in maintenance of pluripotency. The development of techniques to generate ES cells from fibroblasts may mean that there are no issues regarding this technique while there are still ethical issues for the derivation of ES cells from embryos.

“Adult” stem cells. An "adult" or postnatal (somatic) stem cell is an undifferentiated cell found among differentiated cells in a tissue or organ that can self-renew. Adult stem cells are known to be present in many tissues of the body including the heart (15), the nervous system (16), the gut (17), and the skin (18). Bone marrow stem cells have been investigated extensively. These "niche" specific stem cells are thought to reside in all tissues as a repair mechanism against injury. In theory, these cells could be removed from a patient, incorporated into a tissue construct and put back into the same individual when repair becomes necessary. Because the cells are from the recipient, there is no need for immunosuppression. However, problems with accessibility, low frequency (e.g., there is roughly one stem cell per 100,000 nucleated bone marrow cells), restricted differentiation potential and poor growth limit their usefulness for Tissue Engineering or Regenerative Medicine (5).

Friedenstein and coworkers were the first to report that fibroblast-like cells obtained from bone marrow, and attaching to tissue culture plastic were inherently osteogenic (as quoted in ref. 19). Thereafter, contributions from many laboratories led to the realization that these osteogenic cells were actually capable of differentiating into multiple connective tissue cell types at a clonal level (20), this supported the concept of the existence of mesenchymal stem cell (MSCs) first proposed by Caplan (21). Hence, MSCs are typically defined as adherent, fibroblastoid-like cells that differentiate into osteoblasts, adipocytes and chondrocytes in vitro. This property distinguishes them from the nonadherent hemopoietic stem cells (HSC) found also in the bone marrow. Both HSC and MSCs types of cells display different sets of surface markers. An unprecedented interest has lately been noticed on the use of MSCs removed from umbilical cord blood (22) and Wharton's jelly and the potential of these stem cells for generation of different germ cell lineages (endoderm, mesoderm, ectoderm) $(23,24)$. Cord blood may have advantages over other sources of stem cells and currently provides an alternative solution for bone marrow reconstitution for childhood leukemia (25). The only real stumbling block to a broader application of cord blood transfusion is the necessary expansion of sufficient cell numbers.

It can be said that stem cell therapy was born 50 years ago, when the first bone marrow transplant was carried out in the United States (24). This was followed by two clinical trials using stem cells in children with Osteogenesis Imperfecta by Horwitz et al. (26). Bone marrow stem cells have been used as a potential therapeutic avenue for cardiac failure (27-29) and other ailments.

\section{BIOMATERIALS}

Biomaterials are an important component of Tissue Engineering. Scaffolds can aid in vivo regeneration of the remaining healthy tissue and also guide the formation of tissue from dissociated cells ex vivo and in vivo. Scaffolds aim to provide a 3D physical architecture and chemical environment wherein cells can grow to mimic the in vivo process. Scaffolds are typically fabricated by natural materials, which are inherently bioactive but lack mechanical strength, or synthetic materials, which lack inherent bioactivity but could be mechanically strong and can be fabricated with the desirable macro- (shape) and microarchitecture (pore size, porosity). Numerous types 


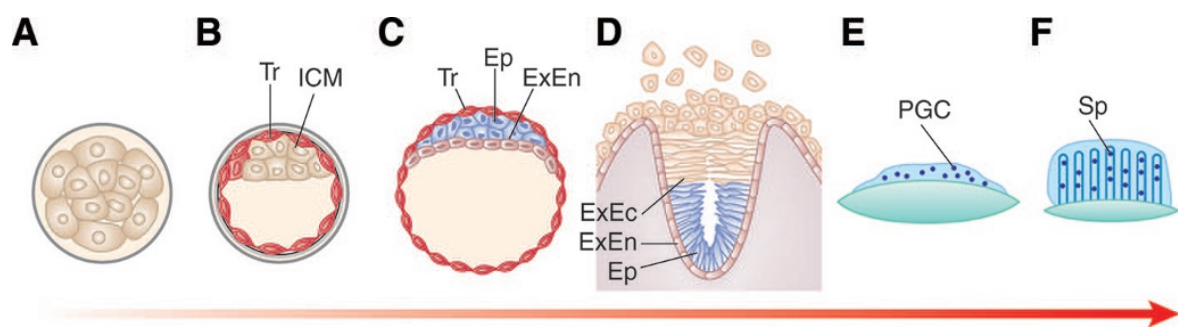

Figure 2. Cells from different stages of development and tissues have different potentialities. Cleavage- and morula-stage embryos are able to give rise to ES cells. (A) Early blastocyst is able to give rise to ES cells from the Inner cell mass (ICM). (B) Late blastocyst is able to give rise to ES cells from the ICM. (C) Six-day postimplantation embryo is able to give rise to EpiSCs from epiblast (Ep) or to teratocarcinomas and embryonal carcinoma (EC) cells. $(D)$ Primordial germ cells from the early (11.5 days) gonad are able to give rise to embryonic germ cells or to teratocarcinomas and EC cells. $(E)$ Spermatogonia from adult testis are able to give rise to ES cell-like cells $(F)$. Reprinted from Lovell-Badge R, Nat Biotechnol 25:1114-1116 @ 2007 Nature Publishing Group, Macmillan Publishers Ltd, with permission.
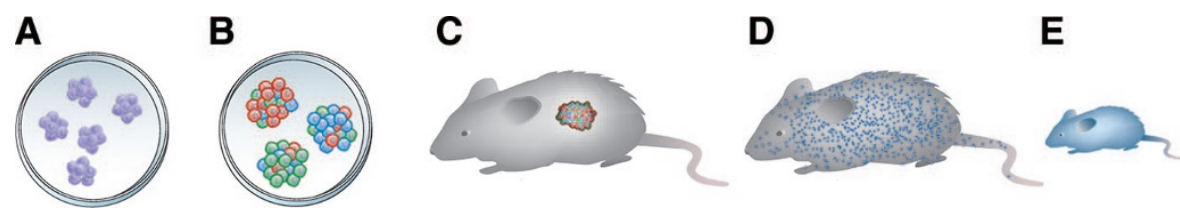

Figure 3. The potential of cultured early embryonic cell types $(A)$ is usually assessed by their ability to differentiate in vitro $(B)$ and in vivo $(C)$ and to contribute to chimeras after injection into blastocysts $(D)$. Undifferentiated EC, ES, ES cell-like, epiblast-like, epiblast stem, and iPS cells $(A)$. Differentiation in vitro $(B)$. Differentiation as teratomas or teratocarcinomas in ectopic sites. $(C)$ Differentiation in chimeras after blastocyst injection $(D)$ and transmission to offspring if the pluripotent cells have contributed to the germline. (E) Fibroblasts from mice can be reprogrammed back to iPS cells. Tr, trophectoderm; ICM, inner cell mass; Ep, epiblast; ExEn, extraembryonic endoderm; ExEc, extraembryonic ectoderm; PGC, primordial germ cells; Sp, spermatogonia. Reprinted from Lovell-Badge R, Nat Biotechnol 25:1114-1116 @ 2007 Nature Publishing Group, Macmillan Publishers Ltd, with permission.

of biomaterials are continually being discovered both manmade or from natural sources. Efforts are currently being carried out to modify the surface of these materials, to guide, and enhance stem cell differentiation (30).

Scaffold should be:

- Biocompatible and biodegradable. Degradation products should be nontoxic.

- Highly porous to facilitate oxygen, nutrients, and waste transfer as well as rapid vascularization and tissue in growth.

- To encourage optimal mechanical properties.

- Be clinically compliant good manufacture practice (GMP).

Initially scaffolds were designed to be bioinert, nowadays biomaterials are made to interact with the cells by being able to release growth factors, genes, or other signals in a timedependent manner $(31,32)$. Scaffolds can be meshes, fibers, porous, solids, or hydrogels.

The material should encourage the cells to attach, proliferate, and differentiate. Some materials are conducive to do this on specific cell types than others. For instance, the behavior of osteoblasts taken from adult bone tissue was analyzed in respect to their behavior to bioglass (33) (a man-made bioactive material) and it was noticed that it elicited cell attachment, cell growth and differentiation in addition to the upregulation of genes involved in osteogenesis with concomitant downregulation of genes involved in other tissue lineages (e.g., fat, endothelium and others) (34-37).

\section{BIOPROCESSING: CURRENT CHALLENGES FOR THE TRANSLATION OF REGENERATIVE MEDICINE RESEARCH INTO PRODUCTS FOR THE HEALTH CARE INDUSTRY}

Bioprocessing for Regenerative Medicine is an entirely new field, which can only be partially compared with that of mass production of molecular medicines. The development of bioprocess technologies for the successful transfer of the current laboratory-based practice of stem cell and tissue culture to the clinic as therapeutics necessitates the application of engineering principles and practices to achieve control, reproducibility, automation, validation, and safety of the process and the product. The successful translation will require contributions from fundamental research (from developmental biology to the "omics" technologies and advances in immunology) and from existing industrial practice (biologics), especially on automation, quality assurance, and regulation. The timely development, integration, and execution of various components are critical.

The ultimate bioreactor is the womb. A baby starts from one cell and grows into a fully differentiated individual. These "natural" bioreactors share common operational characteristics: specifically, mass transport in the form of circulation and diffusion to the cells is excellent-no cell is located more than $400 \mu \mathrm{m}$ from the blood supply. In order for Regenerative Medicine to come of age, there is the need to create optimal bioreactors which will achieve production not by embracing traditional scale-up principles (larger bioreactors) but, through process integration. Monitoring can be performed by realtime, online, and in situ with signal processing and feedback 
being executed coherently. Hence, the optimal bioreactors achieve production through process intensification, modularity, specialization, and integration. The use of bioreactors is critical for Regenerative Medicine applications to achieve control, scale-up, automation, and also for regulatory reasons. The laboratory practices of cell or tissue culture in dishes or flasks would have to be transformed, even in the discovery phase so that bioprocesses are developed that can be directly applied to the clinic.

Traditionally two-dimensional (2D) culture conditions permit only the growth of a small number of cells. Furthermore, 2D culture modality suffers from being cumbersome, timeconsuming, and labor-intensive (38). 2D cultures, in which normal 3D relationships with the extracellular matrix and other cells are distorted, may alter cellular behavior. One of the most significant challenges faced by traditional 2D stem cell culture methodologies is its laborious and arbitrary nature that requires the employment of highly trained operators to conduct routine culture work. Therefore, analyzing cell interactions in more natural 3D settings promises to provide conditions that are closer to what actually occurs in vivo (39).

Much attention has recently been paid to the development of technologies to obtain sufficient number of pure and differentiated functioning stem cells. These include a single-step bioprocess that enables both medium perfusion and direct monitoring of cell viability and metabolite production. Other methods include prevention of ES cell aggregation (e.g., hydrogel encapsulation) and purification of specific cell types (e.g., by genetic manipulation) with medium perfused in a controlled bioreactor environment. These provide a dynamic cultivation system within a controlled environment that enables the expansion of cell populations (40). Bioreactors have been defined as devices in which environmental and operating conditions can be closely monitored and tightly controlled to permit or induce the desired biologic or biochemical process (41) (Fig. 4). These have been used in the field of Tissue Engineering to perform one or more of the following functions: cell expansion (42-47) generation of 3D tissues from dissociated cells and scaffolds in vitro (48-52), and mechanical conditioning of developing tissue (53-55).

Our group at Imperial College has developed a simplified, integrated, and reproducible bioprocess for the production of

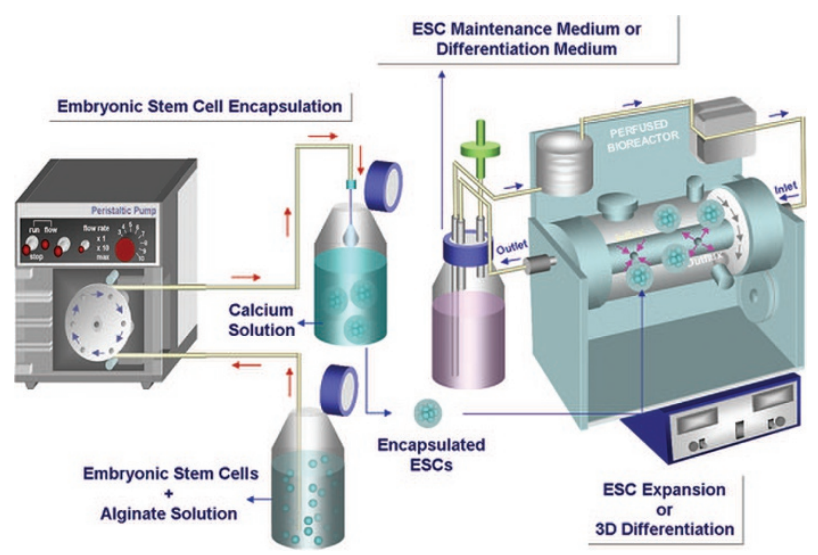

Figure 4. Schematic representation of a bioreactor (Image Courtesy of Dr. Yu-Shik Hwang).
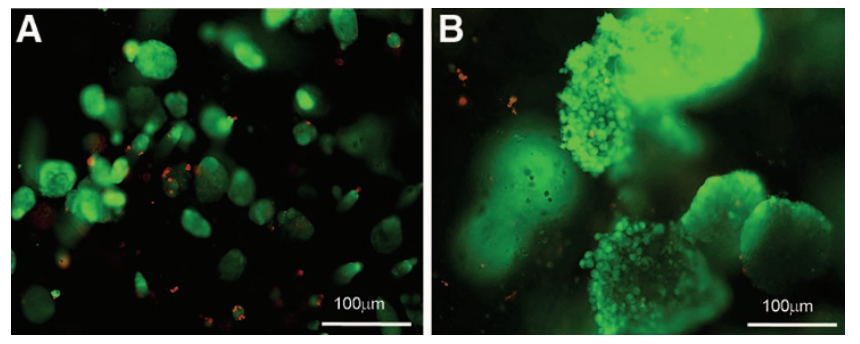

Figure 5. Live or dead assay and morphology of cells and tissues within alginate hydrogels. (A) mESCs in alginate hydrogels at day 5 of culture in a HARV bioreactor. $(B)$ mESCs in alginate hydrogels at day 15 of culture in a HARV bioreactor. Scale bars represent $100 \mu \mathrm{m}$ (Image Courtesy of Dr. Yu-Shik Hwang).

osteogenic cells from mESCs that would be amenable to automation and scale-up for the generation of clinically relevant numbers of high-quality bone cells and mineralized tissue. Specifically, we encapsulated mESCs in alginate hydrogels and cultured them in high aspect ratio vessels (HARV). In this novel, one-step, integrated process, mESC aggregates within alginate hydrogels gradually increased in size maintaining viability in culture Finally, well-developed $3 \mathrm{D}$ viable and metabolically active tissue is noted, as demonstrated by the live or dead assay (Fig. 5). mESCs within hydrogels showed higher viability than when cells were cultured statically in 2D flasks (data not shown). Furthermore, using this integrated process, we differentiated mESCs into osteogenic cells capable of producing 3D mineralized tissue identified by demonstration of stained mineralized aggregates, the expression of osteogenic markers, microcomputerized tomography and FITR, and elemental scanning electron microscopy. Our data indicate that we can potentially generate the equivalent of 20-30 T75 flask cultures in a single $50 \mathrm{~mL}$ bioreactor. Specifically, we have demonstrated an 80 -fold increase in the cell number from a starting density of 10,000 cells/alginate bead to 852,000 cells/bead after 29 days in culture (Fig. 6) (56). We have also successfully encapsulated hESCs within the hydrogels. The cells remain undifferentiated for up to 260 days using both immunocytochemistry and RT-PCR. Alginate encapsulation has been carried out frequently with adult cells $(57,58)$ and more recently, researchers encapsulated ES cells (59) and in Australia, colleagues have encapsulated both mouse and hESCs to treat diabetic patients (60). Normally, alginate hydrogels loose $\mathrm{Ca}^{2+}$ after prolonged

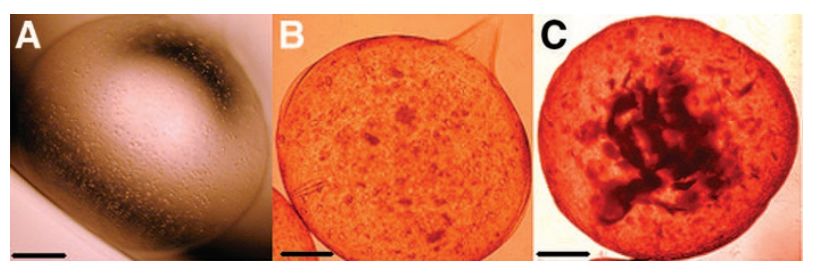

Figure 6. Tissue morphology in the alignate beads. The alignate beads retain their Spherical shape and cell clustering becomes evident: $(A)$ day 3 (scale bar length $-1000 \mu \mathrm{m}$ ); $(B)$ day 7 (scale bar length $-500 \mu \mathrm{m}$ ); $(C)$ day 21 (scale bar length $-500 \mu \mathrm{m}$ ). Hematoxylin and eosin stained thin sections of the hydrogels at various times showing tissue development. Reprinted from Randle WL et al., Tissue Eng 13:2957-2970 @ 2007 Mary Ann Liebert, Inc., with permission. 
culture, but incorporation of gelatin enables cell-mediated contraction and packing of the scaffold material (61).

\section{CONCLUSIONS}

Regenerative Medicine could become a new way of treating injuries and diseases since it can be used to heal, augment, or take over the function of permanently damaged organs. Consequently, Regenerative Medicine stands ready to create the next wave of the biotechnology revolution, following in the footsteps of recombinant proteins and monoclonal antibodies with the potential to impact the whole spectrum of health, from terminal and chronic diseases to cosmetic surgery. It is an entirely new field that brings together expertise in biology, chemistry, engineering, genetics, medicine, and other specialties to find solutions to some of the most challenging medical problems faced by mankind. To date, several engineered skin equivalents and synthetic bone and cartilage composite are commercially available. Efforts are being made to develop cardiac valves, venous and arterial replacement, urological structures, and hematopoietic stem cell products.

Nowadays, Regenerative Medicine and Tissue Engineering are coming of age. It is easy to remember the early days of Tissue Engineering or stem cell therapy where great excitement and false expectations were followed by lack of confidence in particular, from investors. The hope (more likely hype) that was placed in the early days did not live up to these expectations. In consequence, the significant funding that was poured into this newly breaking field caused great disillusion. However, the field is now slowly reaching maturity with realistic expectations, not accepting that the path toward robust clinical products is going to be simple and straight forward. It is likely that there will be disappointments but it is also likely that a new era of novel therapeutic approaches is to be realized. Bioprocessing and commercialization of stem cell or tissue-engineered products in Regenerative Medicine can translate breakthroughs from the research bench to the bedside of the patient. Although many of these tasks cannot be readily addressed and may require long-term commitment, some of the current challenges must remain the primary focus of our research and development. The application of bioprocessing approaches to stem cell and construct production could provide cells in clinically-relevant numbers and with complete biologic standardization, previously unachievable. The intellectual property and know-how concerning the bioprocessing and scale up of cell production will be a core element in any future commercial applications of stem cell biology. However, the need exists to learn how to analyze the cell culture parameters that influence the process and identify the critical ones. One day we might learn what are the essential factors and cues that make the journey from an undifferentiated pluripotent cell to terminally differentiated cells and if we know this, then come, the era of the "regenerative pill" will come to the fore. The challenges that face the field include the need of obtaining "off the shelf" cells that are GMP compliant and immunologic tolerant. There is not, as yet, consensus as to which will be the best cell for clinical applications and it is likely that not one single cell will be the cell to use. As always in medicine, Regenerative Medicine will have to adapt to specific clinical problems and be patient specific. One fact remains clear; there is an urgent need to develop reliable and robust culture procedures that will produce vast quantities of identical batches of cells for a given clinical application.

As Ehrenreich told us: "It will take time, it will take money, it will take patience, there will be setbacks and there will be successes, but over time it is a certainty that biologic methods of tissue repair, replacement and regeneration will come to dominate clinical thinking."

\section{REFERENCES}

1. Dvir T, Benishti N, Shachar M, Cohen S 2006 A novel perfusion bioreactor providing a homogeneous milieu for tissue regeneration. Tissue Eng 12:2843-2852

2. Christodoulou I, Buttery LD, Saravanapavan P, Tai G, Hench LL, Polak JM 2005 Dose- and time-dependent effect of bioactive gel-glass ionic-dissolution products on human fetal osteoblast-specific gene expression. J Biomed Mater Res B Appl Biomater 74:529-537

3. Tsigkou O, Hench LL, Boccaccini AR, Polak JM, Stevens MM 2007 Enhanced differentiation and mineralization of human fetal osteoblasts on PDLLA containing Bioglass composite films in the absence of osteogenic supplements. J Biomed Mater Res A 80:837-851

4. Christodoulou I, Buttery LD, Tai G, Hench LL, Polak JM 2006 Characterization of human fetal osteoblasts by microarray analysis following stimulation with $58 \mathrm{~S}$ bioactive gel-glass ionic dissolution products. J Biomed Mater Res B Appl Biomater 77:431-446

5. Guillot PV, Cui W, Fisk NM, Polak JM 2007 Stem cell differentiation and expansion for clinical applications of Tissue Engineering. J Cell Mol Med 11:935-944

6. Lovell-Badge R 2007 Many ways to pluripotency. Nat Biotechnol 25:1114-1116

7. Evans MJ, Kaufmann MH 1981 Establishment in culture of pluripotential cells from mouse embryos. Nature 292:154-156

8. Thomson JA, Itskovitz-Eldor J, Shapiro SS, Waknitz MA, Swiergiel JJ, Marshall VS, Jones JM 1998 Embryonic stem cell lines derived from human blastocysts. Science 282:1145-1147

9. Brons IG, Smithers LE, Trotter MW, Rugg-Gunn P, Sun B, Chuva de Sousa Lopes SM, Howlett SK, Clarkson A, Ahrlund-Richter L, Pedersen RA, Vallier L 2007 Derivation of pluripotent epiblast stem cells from mammalian embryos. Nature 448:191-195

10. Tesar PJ, Chenoweth JG, Brook FA, Davies TJ, Evans EP, Mack DL, Gardner RL, McKay RD 2007 New cell lines from mouse epiblast share defining features with human embryonic stem cells. Nature 448:196-199

11. Takahashi K, Yamanaka S 2006 Induction of pluripotent stem cells form mouse embryonic and adult fibroblast cultures by defined factors. Cell 126:663-676

12. Okita K, Ichisaka T, Yamanaka S 2007 Generation of germline-competent induced pluripotent stem cells. Nature 448:313-317

13. Takahashi K, Tanabe K, Ohnuki M, Narita M, Ichisaka T, Tomoda K, Yamanaka S 2007 Induction of pluripotent stem cells from adult human fibroblasts by defined factors. Cell 131:861-872

14. Yu J, Vodyanik MA, Smuga-Otto K, Antosiewicz-Bourget J, Frane JL, Tian S, Nie J, Jonsdottir GA, Ruotti V, Stewart R, Slukvin II, Thomson JA 2007 Induced pluripotent stem cell lines derived from human somatic cells. Science 318:1917-20

15. Chien KR, Moretti A, Laugwitz K-L 2004 ES cells to the rescue. Science 306:239240

16. Manganas LN, Zhang X, Li Y, Hazel RD, Smith SD, Wagshul ME, Henn F, Benveniste H, Djuric PM, Enikolopov G, Maletic-Savatic M 2007 Magnetic resonance spectroscopy identifies progenitor cells in the live human brain. Science 318:980-985

17. Barker N, van Es JH, Kuipers J, Kujala $\mathrm{P}$, van den Born M, Cozijnsen $\mathrm{M}$, Haegebarth A, Korving J, Begthel H, Peters PJ, Clevers H 2007 Identification of stem cells in small intestine and colon by marker gene Lgr5. Nature 449:1003-1007

18. Watt FM, Lo Celso C, Silva-Vargas V 2006 Epidermal stem cells: an update. Curr Opin Genet Dev 16:518-524

19. Phinney DG, Prockop DJ 2007 Concise review: mesenchymal stem/multipotent stromal cells: the state of transdifferentiation and modes of tissue repair-current views. Stem Cells 25:2896-2902

20. Pittenger MF, Mackay AM, Beck SC, Jaiswal RK, Douglas R, Mosca JD, Moorman MA, Simonetti DW, Craig S, Marshak DR 1999 Multilineage potential of adult human mesenchymal stem cells. Science 284:143-147

21. Caplan AI 1994 The mesengenic process. Clin Plast Surg 21:429-435

22. Rachakatla RS, Marini F, Weiss ML, Tamura M, Troyer D 2007 Development of human umbilical cord matrix stem cell-based gene therapy for experimental lung tumors. Cancer Gene Ther 14:828-835

23. Weiss ML, Troyer DL 2006 Stem cells in the umbilical cord. Stem Cell Rev 2:155-162

24. Appelbaum FR 2007 Hematopoietic-cell transplantation at 50. N Engl J Med 357:1472-1475

25. Brunstein CG, Barker JN, Weisdorf DJ, DeFor TE, Miller JS, Blazar BR, McGlave PB, Wagner JE 2007 Umbilical cord blood transplantation after nonmyeloablative 
conditioning: impact on transplantation outcomes in 110 adults with hematologic disease. Blood 110:3064-3070

26. Horwitz EM, Gordon PL, Koo WK, Marx JC, Neel MD, McNall RY, Muul L, Hofmann T 2002 Isolated allogeneic bone marrow-derived mesenchymal cells engraft and stimulate growth in children with osteogenesis imperfecta: implications for cell therapy of bone. Proc Natl Acad Sci USA 99:8932-8937

27. Assmus B, Honold J, Schächinger V, Britten MB, Fischer-Rasokat U, Lehmann R, Teupe C, Pistorius K, Martin H, Abolmaali ND, Tonn T, Dimmeler S, Zeiher AM 2006 Transcoronary transplantation of progenitor cells after myocardial infarcation. N Engl J Med 355:1222-1232

28. Lunde K, Solheim S, Aakhus S, Arnesen H, Abdelnoor M, Egeland T, Endresen K, Ilebekk A, Mangschau A, Fjeld JG, Smith HJ, Taraldsrud E, Grøgaard HK, Bjørnerheim R, Brekke M, Müller C, Hopp E, Ragnarsson A, Brinchmann JE, Forfang K 2006 Intracoronary injection of mononuclear bone-marrow cells in acute myocardial infarction. N Engl J Med 355:1199-1209

29. Schächinger V, Erbs S, Elsässer A, Haberbosch W, Hambrecht R, Hölschermann H, Yu J, Corti R, Mathey DG, Hamm CW, Süselbeck T, Assmus B, Tonn T, Dimmeler S, Zeiher AM; REPAIR-AMI Investigators 2006 Intracoronary bone marrowderived progenitor cells in acute myocardial infarction. N Engl J Med 355:12101221

30. Evans ND, Gentleman E, Polak JM 2006 Scaffolds for stem cells. Mater Today 9:26-33

31. Langer R, Vacanti JP 1993 Tissue Engineering. Science 260:920-926

32. Leor J, Amsalem Y, Cohen S 2005 Cells, scaffolds, and molecules for myocardial Tissue Engineering. Pharmacol Ther 105:151-163

33. Hench LL 1998 Biomaterials: a forecast for the future. Biomaterials 19:1419-1423

34. Xynos ID, Hukkanen MV, Batten JJ, Buttery LD, Hench LL, Polak JM 2000 Bioglass 45S5R stimulates osteoblast turnover and enhances bone formation in vitro: implications and applications for bone Tissue Engineering. Calcif Tissue Int 67:321329

35. Xynos ID, Edgar AJ, Buttery LD, Hench LL, Polak JM 2000 Ionic products of bioactive glass dissolution increase proliferation of human osteoblasts and induce insulin-like growth factor II mRNA expression and protein synthesis. Biochem Biophys Res Commun 276:461-465

36. Xynos ID, Edgar AJ, Buttery LD, Hench LL, Polak JM 2001 Gene-expression profiling of human osteoblasts following treatment with the ionic products of Bioglass 45S5 dissolution. J Biomed Mater Res 55:151-157

37. Hench LL, Polak JM 2002 Third-generation of biomedical materials. Science 295:1014-1017

38. Smith AG 1991 Culture and differentiation of embryonic stem cells. J Tissue Cult Methods 13:89-94

39. Yamada KM, Clark K 2002 Cell biology: survival in three dimensions. Nature 419:790-791

40. Zandstra PW, Nagy A 2001 Stem cell bioengineering. Annu Rev Biomed Eng 3:275-305

41. Martin I, Wendt D, Heberer M 2004 The role of bioreactors in Tissue Engineering. Trends Biotechnol 22:80-86

42. Boudreault P, Tremblay JP, Pepin MF, Garnier A 2001 Scale-up of a myoblast culture process. J Biotechnol 91:63-74

43. Liu JY, Hafner J, Dragieva G, Burg G 2004 Bioreactor microcarrier cell culture system (Bio-MCCS) for large-scale production of autologous melanocytes. Cell Transplant 13:809-816
44. Kino-Oka M, Umegaki R, Taya M 2005 Bioreactor design for successive culture of anchorage-dependent cells operated in automated manner. Tissue Eng 11:535-545

45. Monga SP, Hout MS, Baun MJ, Micsenyi A, Muller P, Tummalapalli L, Ranade AR, Luo JH, Strom SC, Gerlach JC 2005 Mouse fetal liver cells in artificial capillary beds in three-dimensional four-compartment bioreactors. Am J Pathol 167:1279-1292

46. Youn BS, Sen A, Kallos MS, Behie LA, Girgis-Gabardo A, Kurpios N, Barcelon M, Hassell JA 2005 Large-scale expansion of mammary epithelial stem cell aggregates in suspension bioreactors. Biotechnol Prog 21:984-993

47. Gilbertson JA, Sen A, Behie LA, Kallos MS 2006 Scaled-up production of mammalian neural precursor cell aggregates in computer-controlled suspension bioreactors. Biotechnol Bioeng 94:783-792

48. Chen HC, Lee HP, Sung ML, Liao CJ, Hu YC 2004 A novel rotating-shaft bioreactor for two-phase cultivation of tissue-engineered cartilage. Biotechnol Prog 20:18021809

49. Williams C, Wick TM 2004 Perfusion bioreactor for small diameter tissueengineered arteries. Tissue Eng 10:930-941

50. Mahmoudifar N, Doran PM 2005 Tissue Engineering of human cartilage and osteochondral composites using recirculation bioreactors. Biomaterials 26:70127024

51. Janssen FW, Oostra J, Oorschot A, van Blitterswijk CA 2006 A perfusion bioreactor system capable of producing clinically relevant volumes of tissue-engineered bone: in vivo bone formation showing proof of concept. Biomaterials 27:315-323

52. Song K, Yang Z, Liu T, Zhi W, Li X, Deng L, Cui Z, Ma X 2006 Fabrication and detection of tissue-engineered bones with bio-derived scaffolds in a rotating bioreactor. Biotechnol Appl Biochem 45:65-74

53. Mol A, Driessen NJ, Rutten MC, Hoerstrup SP, Bouten CV, Baaijens FP 2005 Tissue Engineering of human heart valve leaflets: a novel bioreactor for a strainbased conditioning approach. Ann Biomed Eng 33:1778-1788

54. Seidel JO, Pei M, Gray ML, Langer R, Freed LE, Vunjak-Novakovic G 2004 Long-term culture of tissue engineered cartilage in a perfused chamber with mechanical stimulation. Biorheology 41:445-458

55. Jeong SI, Kwon JH, Lim JI, Cho SW, Jung Y, Sung WJ, Kim SH, Kim YH, Lee YM, Kim BS, Choi CY, Kim SJ 2005 Mechano-active Tissue Engineering of vascular smooth muscle using pulsatile perfusion bioreactors and elastic PLCL scaffolds. Biomaterials 26:1405-1411

56. Randle WL, Cha JM, Hwang YS, Chan KL, Kazarian SG, Polak JM, Mantalaris A 2007 Integrated 3D expansion and osteogenic differentiation of murine embryonic stem cells. Tissue Eng 13:2957-2970

57. Sun AM, Parisius W, Macmorine H, Sefton MV, Stone R 1980 An artificial pancreas containing cultured islets of Langerhans. Artif Organs 4:275-278

58. Sefton MV, Broughton RL 1982 Microencapsulation of erythrocytes. Biochim Biophys Acta 717:473-477

59. Magyar JP, Nemir M, Ehler E, Suter N, Perriard JC, Eppenberger HM 2001 Mass production of embryoid bodies in microbeads. Ann N Y Acad Sci 944:135-143

60. Foster JL, Williams G, Willimas LH, Tuch BE 2007 Differentiation of transplanted microencapsulated fetal pancreatic cells. Transplantation 83:1440-1448

61. Awad HA, Wickham MQ, Leddy HA, Gimble JM, Guilak F 2004 Chondrogenic differentiation of adipose-derived adult stem cells in agarose, alginate, and gelatin scaffolds. Biomaterials 25:3211-3222 